

Canadian Journal of Action Research

Volume 20, Issue 3,2020 , pages 74-100

\title{
EXPLORING THE IMPACT OF CRITICAL PEDAGOGY: DO PRESERVICE TEACHERS DEVELOP CRITICAL CONSCIOUSNESS WHEN TAUGHT BY CRITICAL PEDAGOGUES?
}

\author{
Barbara Pollard \\ University of Windsor
}

\begin{abstract}
The study utilized participatory action research and grounded theory methods and methodology to explore how critical pedagogy, as practiced by a small group of university education professors, shapes and influences the development of a critical consciousness among preservice teachers. Although there were some 'conscious raising' learning experiences, which are highlighted in this paper, the majority of preservice teachers exited the program with limited levels of critical consciousness. This paper discusses some of the pedagogical practices that hindered and enhanced preservice teacher conscious raising as well as the exit data which conveyed three variant levels of critical consciousness.
\end{abstract}

KeY WoRDS: Critical consciousness; Teacher candidates; Critical pedagogy; Inequality; Systemic inequity

\section{INTRODUCTION}

Teacher education programs are challenged with adequately preparing preservice students with the knowledge, skills, and dispositions to work successfully with a wide range of diverse students (Apple, 2001; Chubbuck, 2010; Cochran-Smith \& Zeichner, 2005). Especially challenging, then, is preparing teacher candidates to productively and thoughtfully engage students from diverse and marginalized backgrounds. In theory, critical pedagogy is positioned as a useful approach in facilitating critical consciousness among preservice students who do not already possess the sociocultural lens essential for better understanding their students. Unfortunately, facilitating critical consciousness among preservice teacher candidates is a challenging task that is often not met with success (Egbo, 2012). Nonetheless, the 
importance of understanding the systemic inequities in society in order to better accommodate students cannot be overstated. As Darling-Hammond (2000) emphasizes, "Developing the ability to see beyond one's perspective, to put oneself in the shoes of the learner and to understand the meaning of that experience in terms of learning, is perhaps the most important role of universities in the preparation of teachers" (p. 170).

Chubbuck (2010) claims that critical pedagogy is one of the most challenging pedagogies because it prompts preservice teachers to examine the complex intersection and overlay of multiple systems of oppression and privilege, with the aim of actively working toward social change. For instance, Chubbuck (2010) emphasizes that educators practising critical pedagogy aim to:

Recognize the need to look beyond the school context and transform any structures that perpetuate injustice at the societal level as well ... provide curriculum and instruction that challenge all the students to envision themselves as active citizens with the power to transform unjust structures. (p. 199)

The key goal of critical pedagogy, then, is to facilitate the development of skills and knowledges that are thought necessary for students to be able to critically assess and evaluate inequitable societal structures and practices and act as agents of change (Giroux, 1988a; McLaren, 2009). In other words, once students have started to become critically conscious, critical pedagogues hope that these students will collectively organize and actively work to transform the discriminatory structures, such as racism, classism, and sexism, that unjustly exploit and marginalize historically disadvantaged populations (Freire, 1970; Giroux, 1988b; McLaren, 2009).

The theoretically dense and often perplexing goals of critical pedagogy are clearly and frequently stated in the academic and educational research (see, for example, the work of Freire, 1973, 1973; Giroux, 1992, 2012; Janks, 2010; Shor \& Pari, 1999). However, research illustrating how the goals of critical pedagogy-especially the process of acquiring critical consciousness and developing a "language of critique"are worked out and achieved in the real day-to-day preservice teacher classroom is limited (for a discussion on the lack of research in this area, see Morrison, Robbins, \& Rose, 2008; Cochran-Smith, Davis, \& Fries, 2004; Solomon, Portelli, Daniel, \& Campbell, 2005; Solomon, Singer, Campbell, \& Allen, 2011). I argue that in understanding the educational experiences that facilitate the development of a critical consciousness, critical pedagogues and their students may be able to achieve this goal more effectively. Since "critical consciousness is the prerequisite for societal transformation, emancipation and liberation" (Morrison et al., 2008, p. 452), the importance of developing this state of thinking is difficult to overstate. This study set out to answer the following primary research question: How does critical pedagogy, as practised by a small group of teacher educators in a Faculty of Education, influence preservice teacher candidates' development of critical consciousness? 
For the purpose of this study, critical pedagogy and the facilitation of critical consciousness is described as making the "political more pedagogical" by prompting "agents to enunciate, act, and reflect on themselves, their relations to others, and the wider social order" (Giroux, 2004, p. 499). In other words, critical consciousness is conceptualized as a complex educational process of learning, focused on achieving an in-depth understanding of inequitable structures (e.g., racism, classism, sexism) that in turn enables a form of politicized action (Freire, 1973; McLaren, 2009).

\section{ReSEARChER Positionality}

My background, which influences my perspective, research, and writing, is that of a White, middle-class, able-bodied, heterosexual woman who recently worked through Ontario's higher education system. As such, I have currently experienced privileges afforded by factors such as class, race, sexuality, and physical ability; yet at the same time, being a woman and an immigrant from Poland and raised in a working-class community, I have also experienced forms of discrimination based on my gender, ethnicity, and class. The interconnected and overlapping ways in which these complex factors have both helped and hindered my life were largely obscured prior to entering graduate school. It was only after entering graduate school that I began to develop a mature critical consciousness and acquire a "language of critique," which together helped me better understand how oppressive social relations work. For example, I have grown to understand the powerful ways in which White privilege (Case, 2013) can provide some people, including myself, with unearned privileges, but at the same time, can function to oppress other groups. My personal and professional interest, then, for research and teaching for social justice originates from a personal history with gender and class inequity.

\section{Methodology AND MeThodS}

This study drew on critical theory (Apple, 2001; Giroux, 1992; Gramsci \& Marzani, 1957; Marx, 1894/1985) and utilized a participatory action research approach (Freire, 1971, 1985; Baum, MacDougall, \& Smith, 2006) along with constructivist grounded theory for data analysis and theory building (Charmaz, 2006, 2008). This section describes some relevant aspects of particpatory action reseach (PAR) and constructivist grounded theory to contextualize the research approach. As emphasized by Baum, MacDougall and Smith (2006),

PAR seeks to understand and improve the world by changing it. At its heart is collective, self-reflective inquiry that researchers and participants undertake, so they can understand and improve upon ... the situations in which they find themselves. (p. 854)

Within this particular PAR context, the student participants were positioned as the experts since they were physically and mentally immersed in the teaching and learning context being studied. To elaborate, examining the lived educational experiences conveyed by the preservice teacher participants ensured that the most 
relevant phenomena would be considered. In addition, PAR carved out a formal space for student participants to be involved in making positive changes to the problematic critical teaching and learning context of this particular Faculty of Education. The student participants knew their voices would be heard and many students seemed empowered by being part of a louder collective voice that would act as a conduit for change.

What sets Charmaz $(2006,2008)$ apart from the earlier, classical work of grounded theorists such as Glaser and Strauss (1967; see also, Glaser, 1978, 1992; Strauss \& Corbin, 1998) is her constructivist approach to grounded theory. ${ }^{1}$ In fact, Charmaz is considered to be the "first researcher to describe her work explicitly as constructivist grounded theory" (Mills, Bonner, \& Francis, 2006, p. 717). Constructivist grounded theory contrasts with the approaches of Glaser and Strauss (1967) and of Strauss and Corbin (1998), which take a more 'positivist,', 'objectivist' understanding of the world. The problem with earlier positivist approaches to grounded theory, according to Charmaz (2008), is that they did not attend to how the researcher affected the research process, produced the data, and represented the data, nor did they take into careful consideration how researchers positioned their analyses. In contrast, a constructivist grounded theory, aligning with the tenants of PAR, emphasizes that a complex "interrelationship" exists between the researcher and the participant (Mills, Chapman, Bonner, \& Francis, 2007), and acknowledges that the researcher is an active "passionate participant" (Lincoln \& Guba, 2000, p. 166).

Moreover, the early epistemological stance taken by Glaser and Strauss (1967) was grounded in positivist roots that adopted the notion of researcher objectivity and claimed their emergent theoretical knowledge was discovered in the data and was separated from the social scientists doing the observing. For Glaser and Strauss, objectivity was a central premise in their research paradigm. Objectivist versions of grounded theory assume a single reality that is discovered by a passive, neutral researcher who bracketed their values and biases. Assumptions of objectivity and neutrality make data selection, collection, and representation unproblematic. For earlier "objectivist" grounded researchers, new knowledge and insights were positioned as "givens," rather than constructions that occurred during the research process (Charmaz, 2008, p. 398; Freire, 1971, 1985).

Utilizing the principles of PAR and constructivist grounded theory, this study set out to understand the critical learning experiences of preservice teachers by documenting what participants were thinking, feeling, and doing within the context being studied (Freire, 1971, 1985; Charmaz, 2010). Thus, this research combines the taken-for-granted educational experiences conveyed by preservice teacher participants and my own perspective of the researcher who seeks causal explanations (Burawoy, Burton, Ferguson, \& Fox 1991).

${ }^{1}$ It is interesting to note that, as a doctoral candidate at the University of California, Kathy Charmaz was a student of Barney Glaser. In addition, Anselm Strauss was her dissertation chair (See Charmaz, 2006, p. xii). 


\section{Description of the Research Context: Faculty of Education}

This study took place within one Faculty of Education located in Canada. There were 395 students enrolled in the program for this particular school year (257 women and 138 men). This Faculty of Education makes mention that the full-time faculty make up the most diverse teaching staff in all of Ontario. The faculty also states its commitment to social justice. However, the mechanisms or processes by which students are to be engaged in committing to equity and social justice are not specified in existing policy documentation or other related materials.

\section{Data Collection}

Seven Professors Self-Identified as Critical Pedagogues: Almost 8 hours of data was collected from seven teacher educators who self-identified as critical pedagogues (see Appendix A for the Interview Script utilized during the interviews with professors). The data collected from the professors was mostly descriptive in nature and conveyed the critical teaching philosophy, teaching practices, and learning outcomes endorsed by the teacher educators. As Breuing (2011) has shown, self-identified critical pedagogues enact a range of critical theory. Therefore, when interviewing the professors who self-identified as critical pedagogues, I was especially careful to document the "specific definitions attached to critical pedagogy," the meaning(s) attributed to social justice educators, the "theorists and specific theory" referred to, and "the central aims and purposes" intended, and the intended practices to reach these aims and purposes (Breuing, 2011, p. 8). The overall purpose of these interviews was to ensure that this group of professor participants not only identified as critical pedagogues but also intended to practice critical pedagogy in their classrooms throughout the duration of the school year.

Thirty seven preservice teachers volunteered for the study: The bulk of the data collection and data analysis centered on a diverse group of 37 preservice teacher participants. Almost 60 hours of interview data was collected during the first two weeks of the Faculty of Education school year, and then again toward the end of the school year. Phase One data consisted of open-ended, semi-structured interviews, and was utilized to begin to understand the core values of students, the cultural understandings preservice teachers carried, the meanings they attributed to social justice teaching, and their understanding of structural inequities. These initial probes (See Appendix B for Phase One Interview Questions) enabled a partial understanding of how critical consciousness was understood by each preservice teacher. After collecting Phase One data from all 37 preservice teacher participants, I transcribed the digitally recorded interviews and began the initial coding analysis which formed the initial stages of theory building (Charmaz, 2006).

Keeping the guidelines for intensive interviewing in mind, as suggested by Charmaz (2006), and drawing from the analysis gathered from Phase One of the data collection process, I began Phase Two data collection. The second phase of data collection further explored what specific experiences contributed to the participants' critical 
consciousness and their views on teaching for social justice (See Appendix C for Phase Two Interview Questions).

The preservice teacher participant sample included 25 female students and 12 male students for a total of 37 . The majority of preservice teacher participants were between the ages of 21 and 29 with the exception of six students who were between the ages of 31 to 37 , and one student who was 59. Therefore, 30 of the preservice teacher participants were young adults and 7 of the participants were more mature adults whose responses indicated more extensive work and life experience.

\section{RESULTS}

Before discussing the results, it is pertinent to note that PAR (Baum, MacDougall, \& Smith, 2006; Freire, 1971, 1985) and the constructivist grounded methodology (Charmaz, 2010) utilized for data collection and theory building espouse the following key assumptions: Reality is multiple, processual, and constructed. Ontologically speaking, following Freire $(1971,1985)$ and Charmaz (2010), I understand meaning to be socially constructed, accepting the notion that there are multiple realities as opposed to a single "Truth" (Charmaz, 2008, 2010; Freire, 1985). Following Charmaz $(2008,2010)$, I assume an "observer-relative" constructivist understanding of the data, which, as Guba and Lincoln (1989) note, denies "the claim that there is an objective reality" (p. 43). I acknowledge that relevant interpretations of critical consciousness have been co-constructed by the participants and myself and represent partial truths that are context and time dependent.

\section{Dialogical Learning Contexts vs. Lecture-Based Pedagogy in the Facilitation of Critical Consciousness}

In addition to the outcome-oriented categories of critical consciousness (these are discussed in the next section), the data suggested that there were two mediating themes that influenced the development of critical consciousness: dialogical learning contexts and lecture-based pedagogy. Process-oriented data highlighted some key temporal and contextual issues while providing the thick data necessary to move from description to constructionist interpretation (Charmaz, 2010). A constructionist interpretation is positioned as an extended logic that may reasonably explain some aspects of the descriptive data.

Dialogical Learning Contexts: Within the course based teaching and learning environment, facilitating critical consciousness was linked to educational contexts that were "dialogical" (Shor, 1993). Dialogical learning contexts embody professors who are respectful and responsive to student voices, choices, and autonomy, and who ensure that "students are doing education and making it, not having education done to them or made for them" (Shor, 1993, p. 33). Dialogue is an essential layer of dialogical learning contexts. Furthermore, dialogue has been described as a fundamental component of critical pedagogy and the basis of democratic education that ensures a democratic state (Giroux \& McLaren, 1994). Through dialogue, a classroom can be made into a public sphere, a particular site of active citizenship 
construction in which students and teachers can engage in the process of deliberation and discussion.

Most preservice teacher participants enrolled in Professor K's and Professor G's course conveyed that they were engaged in "dialogical learning" contexts that positively developed their critical lens (Shor, 1993). As you will see in the next section, the discussion-based pedagogical approaches utilized by these two professors were thematically referenced as providing key critical learning experiences.

Pedagogical Approaches Delivered by Professor K: For example, when describing which experiences had the greatest impact on developing her awareness and understanding of key social issues, Jacklyn highlighted the following:

I would say definitely Professor K's course, during our actual class times. We had multiple guest speakers from multiple groups, all kinds of guest speakers, people from all kinds of perspectives. When you get the story from the real person - it is real - it is not just reading the text or reading a story. We had someone live in poverty and had been a single parent and understood what the reality of the situation - you get the real story - it is also hard. But it validates people when they get to share their views on things. They validate why things happen and how they happen, and how you can change these things from happening.

From a critical pedagogical approach, what better place to begin to understand the power to teach for social justice than with life stories. Personal narratives are powerful tools that can be used for unearthing how overlapping systems of oppression and privilege have real material consequences in the lives of everyday people with a view to developing a critical consciousness. In this particular example, Jacklyn illustrates how the personal and lived narratives shared by these guest speakers disrupted the dominant technocratic rationale subsumed in the transmission mode of education, as "private" personal histories and struggles crossed over into the public educational teaching and learning practice. In this context, we see how the transmission mode of education with a technocratic emphasis has been disrupted as the education practice becomes a "humanizing practice" (Freire, 1985) that at least, temporarily and partially, works toward "building a new social order" (McLaren, 1994).

For another case in point, Scott describes his most powerful critical learning experience in the following way:

Professor $K$ had a large variety of speakers come in, suicide, touched on lots of hard-hitting topics. LGBT this was another prominent one, had different people come in and really wrung true that there is lots of diversity out there. Professor $K$ has a variety of events. One guy that really resonated, carried the most, came in and formed a GSA [Gay Straight Alliance], he was the first [First teacher, in this 
area, to do this] and had the biggest impact on me. Thought it was really special, I don't know anyone close to me to who is gay so it really resonated, they should not be marginalized or discriminated against. He [guest speaker] had a practical way to convey the values I have. I walked around GSA billboards in my schools [Practice Teaching Placements] and never paid attention to it until he came and spoke about it.

Scott highlights how Professor K organized the course in ways that are firmly situated in the traditions of critical pedagogy as education was positioned as a form of empowerment and a tool for social change. Teaching with a political intent and with a vision for social change, the personal stories told by the guest speakers helped Scott draw a connection between classrooms and the world outside in a way that he now "pays attention" to critical issues that in the past he overlooked.

The personal narratives told by the guest speakers within the context of the Professor K's course seemed to be a productive pedagogical approach as it had a powerful impact on students. Deanna, an energetic preservice teacher participant who was committed to working towards gender equity, spoke about Professor $\mathrm{K}$ in the following way:

[Professor K's] course was the best course in terms of gaining knowledge on issues of social justice. A lot of social justice had come from this [Professor K's] course. The instructor invited multiple guest speakers giving really informed info on different aspects of social justice. Most enriching experiences at the faculty was bringing these speakers in, especially when teaching in this area. The topics covered were focused on in risk youth. Speakers spoke about resources available to teachers and spoke about what to look for in students. Huge difference between theory and practice and it is very powerful to hear the experiences of experts and of individuals going through the issues or directly working in these areas.

Transforming classroom practices is centrally, but not exclusively, about transforming relations of power in the classroom, relations between teacher and student, and relations between and among students. It was the personal narratives told by guest speakers that seemed to penetrate the consciousness of students to transcend many of the taken for granted stereotypes linked to minority groups.

Jadyn further speaks to the positive impact of the pedagogical approach taken by Professor K:

Very overwhelming when you think about it, will carry these forward. Some of the speakers were educators. The approach [by Professor K] really goes past the classroom. The support [from instructor], comradery [from instructor and peers], personal mentors [speakers and instructor], showed us that you must be real with students. When you empathize with students, you understand the 
students more. You can connect with them more, very informative and enlightening.

Here we can see how Jadyn's desire to construct caring and empathetic relationships is grounded in the idea of mutual respect between herself and her future students. By being an empathetic teacher, she can begin to understand students in holistic and complex ways. hooks (1994) emphasizes the need for educators to consider the complex experiences of their students both inside and outside of school. This fits with the understanding, within the context of critical pedagogy, that education is about more than achieving academic success or becoming a professional.

The critical educational context designed by Professor K offered Jadyn opportunities to increase her awareness around key social issues, which has helped her reshape and rethink her pedagogical practices. Freire's (1985) humanizing practice is evident here as the emphasis is on helping the students acknowledge and address the various issues and struggles their future students may face both inside and outside of the school context. This critical understanding nudges Jadyn to deepen her critical consciousness.

Professor K was not the only instructor that seemed to help students develop a more sophisticated critical consciousness. Professor G was also cited as significantly contributing to the development of the preservice teachers' developing a critical lens.

Pedagogical Approaches Delivered by Professor G: The participants enrolled in Professor G's course also reported developing their critical lens as a result of the learning activities that took place in this class. For example, when asked to reflect on the course that most contributed to developing her critical lens, Jordan responds:

We have a class with Professor G. Every week we talk about some social justice issues, racism, white supremacy, gender based discrimination. So obviously at the beginning of the school year she described the issues and topics that come and that no two students are alike and stuff like that.

Deanna, who was enrolled in both Professor G's and K's course mentioned that these two classes complimented each other: Professor G's class was cited as "providing a good equity focused theoretical base" and "Professor K featured many powerful guest speakers that spoke about these various inequities from first-hand experience." Deanna reflects on what she had learned by being in both of these classes:

I am so lucky and blessed to have taken what I have and absorbed what I have. The whole idea of taking a walk in another person's shoes. I am a White middle class privileged woman. I have been sheltered from issues that I have never been through nor could I imagine. But being open and listening and be able to look at students when you are in a classroom. Teach as if everyone is the same but be sure 
students know and learn about the differences. Must be informed about the differences in order to create an acceptance.

The critical learning experiences stemming from the pedagogical approach taken by Professor G and Professor K, prompted Deanna to apply her critical theoretical insights to her own personal life by reflecting on her own White, middle class, privilege, at least to some degree.

It is important to note that Professor G did not rely on a lecture-based pedagogy; the course was a discussion based course. As conveyed by Deanna:

Professor $G$ would re-iterate one or two key concepts from the assigned chapters for the first 10 to 15 minutes of class. We would then get into our groups [discussion groups of 5/6 students] and discuss and respond to the questions posed. Towards the end of class, Professor $G$ offered us different formats for sharing our answers with the bigger group [the entire class].

Deanna went on to explain that Professor G was one of the few professors that "did not lecture for the whole class period." Rather, the students were given class time to engage in meaningful dialogue and were encouraged to share their group's ideas through various forums, such as the course website discussion board, in-class traditional oral sharing, and constructing anonymous written responses on sticky notes and posting these to a delegated wall in the classroom for all to view.

Bobbie, a proficient English Language Learner, also credits Professor G, as being the most helpful in developing his views of diverse students:

Yes, it [view of diverse students] has changed a lot. For the diverse student, mostly Professor G's course. [Professor G] showed us that when it comes to diversity and working with students, we must put in our lesson plans, will have different students in your classroom. For example, ESL [English as a Second Language], home problems. Must have different instructions and activities.

Influenced by Professor Gs' course, Bobbie now better understands the importance of taking into careful consideration students' needs while planning. Moreover, Bobbie has considered the need to engage in democratic practices by sharing authority between students and teachers and making room for students to be experts in the classroom. Bobbie explained: "[S]tudents should be part of the lesson plans, should decide how they want to do assignments and how to be motivated."

Anne also attributed her evolving critical consciousness to her educational experience in Professor G's course: "Professor G was a tremendously wonderful professor that spoke about how students learn in different ways, learning to shape info so that you are inclusive of all students. Professor G was really good at this." 
When asked what educational experiences within the faculty had the greatest impact on preservice teachers' knowledge for developing a critical perspective, Dan responded: "Professor G's course laid the framework for us because a lot of us were not familiar with these concepts. I am a history major and was not aware of many of these concepts." Dan attributes his developing critical views to his educational experience in Professor G's course:

Before the program, I thought of diversity as simply race. He is Lebanese, he is Italian, whatever. Now, diversity could be based on needs, gender, religion, sexual orientation, religion, so many variables and criteria. That social issues class [Professor G's course] brought it to prominence. Professor G's class is very specific and corresponds a lot to social justice which is why I can make the connection. This course explicitly talks about social justice and includes us in the conversations through dialogue and activities.

Similar to Dan, many of the participants reported having significant 'consciousness raising' experiences by being able to discuss these threshold knowledges in small groups. Although most students may not have evidenced a depth of critical knowledge, they were exposed to many new social justice issues and many relevant diverse perspectives. At minimum, these two courses would have positively moved these preservice teachers to a deeper level of critical knowledge, and consequently, they would be better positioned to potentially resist some forms of thinking and acting that reproduce the status quo. I now turn the discussion to how the preservice teachers viewed lecture-based courses as negatively impacting the development of critical consciousness.

The Lecture: Many participants mentioned that most of the other professors, more often than not, adopted lecturing as their primary pedagogical approach. For this particular sample of preservice teachers, the lecture-based pedagogy functioned to inculcate students while also eliminating the critical dialogue necessary to facilitate a critical consciousness. For example, Jacob felt that in order to more effectively develop socially just teachers, the faculty should eliminate ineffective lecture-based courses: "One thing for sure is to get rid of lecture style classes. In a lecture-based class, you can't have a discussion, you can't have a conversation and have students engage." Jacob goes on to make special mention that in a large class that adopted a lecturebased format, students not only took on a more passive role to learning but were also clearly less likely to participate in class activities or take responsibility for their own learning, and were far more likely to be distracted.

Kyla, another preservice teacher who was disenchanted with lecture-based courses went on to describe what happens to students when faced with a large, lecture-based class: "Just look over a large lecture based course, and you will see the students on their laptops or phones surfing the net, social media, or on Facebook." Kyla goes on: 
I, and so many other people, go into these three-hour lectures and we know we are about to waste time. There is no effort for these topics to be delivered in an attention grabbing form. I feel like there cannot be learning done in that format of a class, [we need] smaller classes, more engaging topics.

Kyla and Jacob articulate themes found in the secondary literature (Mulryan-Kyne, 2010) where students in large classes with a lecture-based format tend to engage in distractions. These include inappropriate use of technology, such as entertaining oneself with an iPhone, or engaging in social media like Facebook (Mulryan-Kyne, 2010). Even in a few of the courses under study, Kyla questioned whether the faculty really seemed to care or notice the level of disengagement among students while in class. Opportunities for faculty-student interaction during the class has been known to play an important role in shaping student engagement in higher order, deeper learning on the part of students.

The above critiques by Jacob and Kyla also have serious consequences for dialogue and its relationship to the development of critical consciousness. Students must be presented with opportunities to consider, discuss, and critically assess the multiple perspectives presented on any one critical issue. This concern has been articulated in the research literature on critical pedagogy (Giroux \& McLaren, 1994; Giroux, 1988a). One does not become critically conscious in an isolated vacuum or echo-chamber.

Other participants conveyed similar sentiments regarding lecture-based classes. Here, Mary describes her experiences in a lecture-based teacher centered classroom, even one taught by a self-identified critical pedagogue:

We are taught in our classes not to teach in a teacher directed way. In [class] we have a prof. that tells us not to stand in front of a class and talk for three hours yet [the professor] does this - [the professor] says do not talk in monotone voice and [they] does this.

The research literature on critical pedagogy emphasizes that critical pedagogues should be open to and reflective on the ways in which their students are responding to the teaching and learning that is occurring. Not being responsive, nor understanding how students are experiencing teaching and learning is a significant limitation when it comes to developing critical consciousness.

Within teacher education, professors committed to a stance of social justice, and in particular those who engage in and practice critical pedagogy, "must serve as living examples of the very kind of critically oriented pedagogical practices that they seek to have their students adopt" (Liston \& Zeichner, 1987, p. 133). In the next section, I discuss the three levels of critical consciousness the preservice teachers seemed to convey shortly before graduating. 


\section{Differential Levels of Critical Consciousness}

In this section, I describe three levels of critical consciousness that were based on the most salient and repetitive themes realized in the data. Based on the data, the students both entered and exited the program with more or less the same critical lens, with the exception of gaining a surface and technocratic awareness of some issues of inequity, such as white privilege and gender inequity. Thus, there seemed to be little productive movement on the spectrum of critical consciousness development. To exemplify, I move on to discuss the most prominent and common themes emerging from 31 out of 37 preservice teachers.

Limited Level of Critical Consciousness: The data analysis stemming from the interviews conducted in the beginning and end of the Faculty of Education program showed that most preservice teacher participants demonstrated a limited type of critical consciousness (31 out of 37 preservice teacher participants). The limited type of critical consciousness is best summarized as a technocratic view of relative core concepts, such as social class inequity, gender inequity, racism, and diversity. A technocratic rationale is linear in its thinking and assumes simple cause-effect relationships. For example, when asked, "What does teaching for social justice mean to you?" Bobbie, a preservice teacher participant, answered: "Treating everyone equally. Taking into consideration diversity and differentiation of instruction...Some [students] are strong and some are weak. [Teachers] need to divide out time between students based on the need of the students." Similar to Bobbie, this group of preservice teacher participants adopted a technocratic understanding of school and were entangled within traditional functional views of school that rarely take into consideration the broader social forces that "reproduce" the status quo (Giroux 1988b, p. 6).

A deep and lively form of critical consciousness, on the other hand, involves thinking closely about the broader social forces and structures that implicate the schooling experiences of students and teachers (Giroux, 1988b). A traditional functional view of schooling focuses on execution of tasks and objective measurement of academic outcomes, and could be viewed as closely aligned with the current 'standards and accountability movement'. In contrast, a radical critical view of schooling begins with the notion that reality and knowledge should be questioned, analyzed, and made problematic within classroom contexts that emphasize dialogical learning and open debate. The facilitation of critical consciousness inherently subsumes a radical critical view of schooling and sets out to problematize traditional functional notions and applications of schooling (Giroux, 1988b).

The teaching approaches referenced by most preservice teacher participants were vague and often abstract, and were presented as quick fix methods. For example, at the end of the school year, Riley states:

In my undergrad class, I had one prof that talked about the mini max principle and he talked about minimizing differences and maximizing similarities. So focus 
on differences but emphasize the similarities. The similarities do far outweigh the differences and that is how I approach the topic about culture and holidays.

When asked, "What does social justice teaching mean for to you?" Dina replies,

I think social justice is about fairness so everyone regardless of race gender or anything. Everyone is treated fairly. There is no discrimination based on these characteristics. At this stage of my career, I am still trying to work out how to incorporate social justice into my lessons.

As conveyed by Riley and Dina, most preservice teacher participants were also limited in their ability to understand themselves as inhabiting complex intersections of multiple and overlapping social positions not reducible to race, or class, or gender, or sexual orientation and so on. The word "limited" here is crucial for meaning, as it acknowledges the complexity of consciousness and power which recognizes that all social actors, including all preservice students, have some degree "of penetration" of the social forms that both oppress and privilege them (Foucault, 1982; Giddens, 1979; Gramsci, 1971).

It is reasonable to assume that participants with limited types of critical consciousness will not, in the near future, contribute to transforming or resisting inequitable societal structures. As a result, they will not satisfy one of the key aims of critical pedagogy. As emphasized by Giroux (1988b), critical pedagogy and its main goal of facilitating critical consciousness "will have to subordinate technical interests" (p. 20) in a way that the broader social structures and their varied and multiple manifestations and ethical concerns come under close scrutiny.

In any event, this study finds further evidence to support the claim made by Giroux and Aronowitz (2011) that a technocratic rationale continues to reign over the majority of preservice teacher candidates enrolled in faculties of education. The technocratic rationale evidenced in this study seemed to create a barrier to critically assessing the broader, more complex, and more important issues, such as "What is the role of the teacher and what is the purpose of education?"

Preservice teacher participants with limited critical consciousness, to one degree or another, evidenced three reproductive mechanisms when discussing the meaning of social justice, describing social justice teaching practices, and elaborating on issues of class, racism, and gender inequity: (a) a technocratic rationality on matters regarding issues of inequity, which was then associated with (b) a "free floating" (Giroux \& Aronowitz, 2011, p. 46) and apolitical stance, that was accompanied by (c) an internalized hyper-individualism.

When discussing the meanings attributed to social justice and teaching for social justice, most of the preservice teacher participants in this category entered into discourses of multicultural frameworks that lacked complexity, using an equality 
over equity lens, colour blindness, and cultural deficit models of marginalized students. For example, when asked about how race shapes student experiences in Ontario classrooms, Analisa thought it is better to take a colour-blind approach, where "race really doesn't matter." Of course, as Bell, Funk, Joshi, and Valdivia (2016) point out, many educators espouse colour blindness to "assert that they are not racist, as in the phrase 'I don't see colour, I just see people"' (p. 170). By adopting an approach where race isn't 'seen,' Analisa overlooks the cumulative and enduring ways in which race unequally shapes life chances and opportunities for children from different groups, which reinforces and sustains an unequal status quo. Some have argued (e.g., Bonilla-Silva \& Forman, 2000) that colour blindness has become the "new racism," as it positions race as a taboo topic that cannot be openly discussed and makes it much more difficult to address the racial issues that persist in schools.

Thus, the data collected during the interviews seemed to suggest that although most preservice teacher participants (31 out of 37) expressed a genuine interest in teaching for social justice, they had technical and surface levels of critical consciousness. I know turn to discussing a productive type of critical consciousness conveyed by five preservice teacher participants.

Productive Level of Critical Consciousness: Five preservice teacher participants stood out as having a productive level of critical consciousness as they discussed their intention to disrupt status quo teaching practices that contributed to the reproduction of social inequity. This small group of preservice teacher participants was aware of some issues related to social inequity (e.g., racism, class inequity, and gender inequity) and intended to engage in varying 'consciousness raising' teaching practices. It is important to note that this group of preservice participants came into the study with an already evolved critical lens. Their critical knowledge of racism, classism, and sexism was attributed to critically focused undergraduate courses such as Women's Studies and Gendered History.

Unlike the preservice teacher participants with limited critical consciousness, this group of teachers were able to describe disruptive teaching practices. For example, when asked to elaborate on the meaning of 'teaching for social justice,' Caleb responds:

Social justice is about knowing that you don't know and not making assumptions. In my Gendered History course, I had a really good professor. It was always about challenging - not accepting things at face value-or even just hypothesizing. I take this into my [Teaching] practicum.

Caleb's understanding of his role as a "critical intellectual" (Giroux, 1988b, p. 470) embraces uncertainty and then paves the way for his counterhegemonic function as a teacher. To elaborate, here is Caleb citing an example of his socially just teaching practice: 
In history you don't have African Americans involved in history. I researched this and presented it and told students to challenge everything and not accept things for face value. Also it is helpful, from a social justice perspective. I [momentary pause], you, read all white authors, you have a skewed perception.

By thinking clearly and closely about Whiteness as a structural system of power, Caleb seems to have genuinely adopted a critical intellectual role and performs counterhegemonic functions within the formal educational context.

When Emma, another meso level preservice participant, describes her strategic use of multicultural texts, within her teaching placement, she emphasizes the following:

One of the big things is using examples that students can relate to. Especially images, texts should reflect different cultural backgrounds. This may seem so small, but it makes a huge difference if students can see themselves in the material.

Emma implicitly understood that the texts, stories, and media used within classrooms are largely Eurocentric and mostly authored by White males (Friedan, 1963; Holland, 2012; Johnson, 2007). Clearly, Emma, like other preservice teacher participants with a productive critical consciousness, has adopted a student centered, culturally responsive approach to teaching and learning, whereby the students' unique cultural strengths and backgrounds are identified and nurtured to promote student achievement and a sense of well-being about their place and space in the world (Ladson-Billings, 1992, 1994; see also, Portelli, Vilbert, \& Shields, 2007). Preservice teachers with a productive critical consciousness, like Emma, were invested in equity and inclusivity in a way that furthers the aims and goals of social justice. I now move on to discuss the salient themes conveyed by one preservice teacher participant that reflect a transformative level of critical consciousness.

Transformative Level of Critical Consciousness: Only one preservice teacher participant, Nelly, conveyed a transformative level of critical consciousness as she was able to describe and problematize the hierarchical power relations and structural inequity associated with issues of race, class, gender, and sexual orientation. For example, when elaborating on the meaning of 'teaching for social justice' Nelly articulates:

When you are teaching for social justice, it is a political response to an unequal political structure of our society. When we talk about professionalism, we say leave your life out of this, don't talk politics, don't talk religion or money. But yet these are the basic things that influence how we see the world and influence the actions we take and don't take.

Unlike the other preservice teacher participants, Nelly was able to problematize the banking style of education and propose strategies that would serve to create 
dialogical learning contexts. Nelly was the only participant that demonstrated a willingness to facilitate educational contexts that prompt students to become both critically conscious and active in addressing the student-relevant social inequity.

Since Nelly had pursued two years of graduate level knowledge in the area of education, unlike the other preservice teacher participants, she was able to utilize 'an academic language of critique and possibility'. For example, when discussing lecturebased course based learning experiences, Nelly states:

The idea is that the teacher runs the class and the students are passive. Some of the students said that they wanted to speak up in class but they didn't have the language and they may not have been comfortable. They felt as if they were shutting others down. You need to have a certain courage, must know that you are being shut down, so the prof would override what the student is saying or not giving the students air time. Either, the profs feel entitled to take the lead, [or] you are so used to seeing this over and over it simply starts not to phase you anymore.

As shared by Nelly, options to integrate one's voice in a preservice course may be limited, or perceived as impossible, depending on the pedagogical approach and pedagogical goals implemented by the respective professor. Interestingly, Nelly made the concious decision to sometimes refrain from stating her views in class, however, she was also strategic and "careful not to overstep the normative passive student role."

\section{Discussion}

The analysis stemming from the data collected from the preservice teacher participants provides an unsettling story of the overall ineffective facilitation of critical consciousness: Only 2 out of 7 professors were referenced, by their students, as being productive in developing some aspects of their critical lens. In parallel with previous scholarship, the research results suggest that neoliberal driven educational policies (e.g., prioritizing cost efficiency by increasing the quantity of large lecture style courses), which promote and sustain technocratic learning environments, topdown hierarchical power relations, and ideologies such as hyper-individualism, create barriers to facilitating critical consciousness within the context of course based learning.

The pertinent question becomes, how did these two professors (Professor K and G) manage to productively mediate some of the neoliberal barriers and partially facilitate some forms of 'conscious raising'? Although different in content and pedagogical style, Professor K and G were similar in that these Professors created classrooms that explicitly and implicitly emphasized that education is not neutral. These two professors helped students understand that schools are particular sites for organizing knowledge and power. As such, it became possible to view schools as vehicles for change rather than sites for social reproduction. Furthermore, the overall aim of the pedagogical approach of these two professors was to help students explore 
the many taken-for-granted assumptions about the world that often disadvantage some students and privilege others.

As shared by many preservice teacher participants, Professor K and G structured a variety of learning activities that prompted a serious consideration of diverse social justice issues and perspectives. Reflecting aspects of Shor's (1993) dialogical critical pedagogy, these two professors moved preservice teachers beyond simply discussing the issues and into the domain of understanding how individuals and groups may interpret and experience the world. This essentially entailed the process of examining how racial, gender, and social class discrimination is socially constructed and mediated through social relations. Here we see how the political enters the pedagogical and disrupts normative structures such as the top-down power hierarchy and transmission mode of learning inherent in many educational systems.

The importance of dialogue cannot be overstated when discussing the facilitation of critical consciousness. Dialogue has been described as a fundamental component of critical pedagogy and the basis of the democratic education that ensures a democratic state (Giroux \& McLaren, 1994). Through dialogue, a classroom can be made into a public sphere, a particular site of citizenship in which students and teachers can engage in the process of deliberation and discussion. School and classroom practices should, in some manner, be organized around forms of learning which serve to prepare students for responsible roles as transformative intellectuals, as community members, and as critical active citizens outside of school. "A transformative intellectual utilizes the language of critique, problematizes the reproductive aspects of dominant education, and utilizes forms of pedagogy that prompt students to become critical agents" (Aronowitz \& Giroux, 1993, p. 46). As Professor K and G seem to have realized that dialogue entails a dialogical relationship based on the premise that all members have equal opportunity to speak, all members respect other members' rights to speak, and all members feel safe to speak.

The conclusions drawn from the data suggest that only a few teacher candidates conveyed a sense of becoming more critically conscious as a result of the courses they have taken at the Faculty of Education. Within the context of our interviews, most preservice teacher participants tended to convey a "doxic" acceptance of both the world at large and the broader schooling system. Briefly, Bourdieu (1972) employs the term "doxa" to describe the uncritical consciousness held by the majority of the population within any given society. In his well-regarded 1984 work, Distinction: A Social Critique of the Judgment of Taste, Bourdieu describes how "doxa" works in society through individuals to reproduce the status quo. For individuals and groups, doxa works to mask the unequal and inequitable divisions in society by establishing in them unstated, taken for granted assumptions, or simply "common sense" views of the world (Bourdieu, 1984). So internalized are the assumptions, Bourdieu (1984) argues, that people simply "forget" that these assumptions were manufactured by other people. A doxic view of the world, then, sharply contrasts with a deeper more 
lively form of critical consciousness and the cognitive habit of problem posing that Freire (1970) emphasizes in his work.

With the understanding of doxa in mind, it is reasonable to assume that most preservice teacher participants within this sample have internalized the dominant educational practices and ideologies associated with the transmission style of education, educational top-down power hierarchies, and, to some degree, the neoliberal emphasis on hyper-individualism. Teachers and other educators interested in education must work to better understand how the dominant culture functions at all levels of schooling to undermine the cultural, social, political experiences of what Giroux (1992) calls the "excluded majorities" (p. 7). Out of 37 preservice teacher participants, Nelly was the only one to convey a transformative level of critical consciousness during the time of our interviews as she demonstrated a critical intellectual ability to "problematize" schooling and utilize a "language of critique" in a way that would help her students to critically "read the world." Keep in mind that a Faculty of Education oriented toward social justice and inhabited by some instructors who adopt critical pedagogy as an approach ought to be producing many students who have the capacity and the analytical tools to interrogate what "appears to be normal, to challenge the status quo, and to name and change the world, rather than merely interpreting it" (Orelus, 2011, p. 3).

In summary, the lack of critical learning experiences shared by the majority of preservice teachers in this sample suggests that there is an urgent need to reconsider, and productively reconstruct, the educational process of facilitating a critical consciousness, especially when this is the explicit learning outcome. School and classroom practices should, in some manner, be organized around forms of learning which serve to prepare students for responsible roles as transformative intellectuals, as community members, and as critical active citizens outside of school. "A transformative intellectual utilizes the language of critique, problematizes the reproductive aspects of dominant education, and utilizes forms of pedagogy that prompt students to become critical agents" (Aronowitz \& Giroux, 1993, p. 46). To some extent, Professor K and G were able to create learning environments that contributed to raising the consciousness of preservice teachers, however, it seems as if there remains much more work to be done before preservice teachers develop the transformative intellectual skills emphasized by critical pedagogues.

\section{REFERENCES}

Apple, M. W. (2001). Educating the "right" way: Markets, standards, God, and inequality. Hoboken, NJ: Taylor \& Francis.

Aronowitz, S., \& Giroux, H. A. (1993). Education still under siege. Westport, Connecticut: Greenwood Publishing Group. 
Bell, L. A., Funk, M. S., Joshi, K. Y., \& Valdivia, M. (2016). Racism and white privilege. In M. Adams, L.A. Bell, D.J. Goodman \& K.Y. Joshe (Eds.), Teaching for diversity and social justice (3rd ed., pp. 397-418). London, UK: Routledge.

Bonilla-Silva, E., \& Forman, T. A. (2000). “I am not a racist but...”: Mapping White college students' racial ideology in the USA. Discourse \& Society, 11(1), 50-85.

Bourdieu, P. (1972). Systems of education and systems of thought. In M. F. Young (Ed.), Knowledge and control: New directions for the sociology of education (pp. 189-207). London, UK: MacMillon.

Bourdieu, P. (1984). Distinction: A social critique of the judgement of taste. Cambridge, MA: Harvard University Press.

Breuing, M. (2011). Problematizing critical pedagogy. The International Journal of Critical Pedagogy, 3(3), 2-23.

Baum, F., MacDougall, C., \& Smith, D. (2006). Participatory action research. Journal of Epidemiology \& Community Health, 60(10), 854-857.

Burawoy, M., Burton, A., Ferguson, A. A., \& Fox, K. J. (1991). Ethnography unbound: Power and resistance in the modern metropolis. University of California Press.

Case, K. (2013). Deconstructing privilege: Teaching and learning as allies in the classroom. New York, NY: Routledge.

Charmaz, K. (2006). Constructing grounded theory: A practical guide through qualitative analysis. London, UK: Sage.

Charmaz, K. (2008). Constructionism and the grounded theory. In J. A. Holstein \& J. F. Gubrium (Eds.), Handbook of constructivist research (pp. 397-412). New York, NY: Guilford Press.

Charmaz, K. (2010). Constructing grounded theory: A practical guide through qualitative analysis. London, UK: Sage.

Chubbuck, S. M. (2010). Individual and structural orientations in socially just teaching: Conceptualization, implementation, and collaborative effort. Journal of Teacher Education, 61(3), 197-210.

Cochran-Smith, M., Davis, D., \& Fries, K. (2004). Multicultural teacher education: Research, practice, and policy. In J. Banks \& C. McGee Banks (Eds.), Handbook of research on multicultural education (2nd ed., pp. 931-975). San Francisco, CA: Jossey-Bass. 
Cochran-Smith, M., \& Zeichner, K. M. (2005). Studying teacher education: The report of the AERA panel on research and teacher education. Mahwah, NJ: Lawrence Erlbaum.

Darling-Hammond, L. (2000). How teacher education matters. Journal of Teacher Education, 51(3), 166-173.

Denzin, N. K., \& Lincoln, Y. S. (Eds.). (2011). The Sage handbook of qualitative research (4th ed.). Thousand Oaks, CA: Sage.

Egbo, B. (2012). What should preservice teachers know about race and diversity? Exploring a critical knowledge-base for teaching in 21st century Canadian classrooms. Journal of Contemporary Equity Issues, 6(2), 23-27.

Friedan, B. (1963). The feminine mystique. New York, NY: Norton.

Foucault, M. (1982). The subject and power. Critical Inquiry, 8(4), 777-795.

Freire, P. (1970). Pedagogy of the oppressed. New York, NY: Herder \& Herder.

Freire, P. (1971) A Talk by Paulo Freire, Studies in Adult Education. Institute for Adult Education, 2, 1-10.

Freire, P. (1973). Education for critical consciousness. New York, NY: Seabury Press.

Freire, P. (1985). The politics of education: Culture, power, and liberation. South Hadley, MA: Bergin \& Garvey.

Giddens, A. (1979). Central problems in social theory: Action, structure, and contradiction in social analysis. Oakland, CA: University of California Press.

Giroux, H. A. (1988a). Schooling and the struggle for public life: Critical pedagogy in the modern age. Minneapolis, MN: University of Minnesota Press.

Giroux, H. A. (1988b). Teachers as intellectuals: Toward a critical pedagogy of learning. Granby, MA: Bergin \& Garvey.

Giroux, H. A. (1992). Educational leadership and the crisis of democratic culture. University Park, PA: University Council for Educational Administration.

Giroux, H. A. (2004). Public pedagogy and the politics of neo-liberalism: Making the political more pedagogical. Policy Futures in Education, 2(3), 494-503.

Giroux, H. A. (2012). Education and the crisis of public values: Challenging the assault on teachers, students, and public education. New York, NY: Peter Lang.

Giroux, H., \& Aronowitz, S. (2011). Education under siege. South Hadley, MA: Bergin \& Garvey. 
Giroux, H., \& McLaren, P. (1994). Between borders: Pedagogy and the politics of cultural studies. New York, NY: Routledge.

Glaser, B. (1978). Theoretical sensitivity: Advances in the methodology of grounded theory. Mill Valley, CA: Sociology Press.

Glaser, B. (1992). Basics of grounded theory analysis: Emergence vs. forcing. Mill Valley, CA: Sociology Press.

Glaser, B. G., \& Strauss, A. L. (1967). The discovery of grounded theory: Strategies for qualitative research. Chicago, IL: Aldine.

Gramsci, A. (1971). Prison notebooks. New York, NY: International Publishers.

Gramsci, A., \& Marzani, C. (1957). The open Marxism of Antonio Gramsci. New York, NY: Cameron Associates.

Guba, E., \& Lincoln, Y. (1989). Fourth generation evaluation. Newbury Park, CA: Sage.

Holland, J. (2012). A brief history of misogyny: The world's oldest prejudice. London, UK: Hachette.

hooks, B. (1994). Outlaw culture: Resisting representations. London, UK: Routledge.

Janks, H. (2010). Literacy and power. New York, NY: Routledge.

Johnson, A. G. (2007). The gender knot: Unraveling our patriarchal legacy. Delhi, India: Pearson Education.

Ladson-Billings, G. (1992). Culturally relevant teaching: The key to making multicultural education work. In C. A. Grant (Ed.), Research and multicultural Education: From the margins to the mainstream (pp. 101-121). London, UK: Falmer Press.

Ladson-Billings, G. (1994). The dreamkeepers: Successful teachers of African-American children. San Francisco, CA: Jossey-Bass.

Lincoln, Y., \& Guba, E. (2000). Paradigmatic controversies, contradictions, and emerging confluences. In N. K. Denzin \& Y. S. Lincoln (Eds.), Handbook of qualitative research (2nd ed., pp. 163-188). Thousand Oaks, CA: Sage.

Liston, D., \& Zeichner, K. M. (1987). Critical pedagogy and teacher education. The Journal of Education, 169(3), 117-137.

Marx, K. (1985). Capital: A critique of political economy. New York, NY: Vintage Books. (Original work published 1894) 
McLaren, P. (1994). Life in schools: An introduction to critical pedagogy in the foundations of education. New York, NY: Longman.

McLaren, P. (2009). Critical pedagogy: A look at major concepts. In A. Darder, M. P. Baltodano, \& R. D. Torres (Eds.), The critical pedagogy reader (2nd ed., pp. 6183). New York, NY: Routledge.

Mills, J., Bonner, A., \& Francis, K. (2006). The development of constructivist grounded theory. International Journal of Qualitative Methods, 5(1), 672-751.

Mills, J., Chapman, Y., Bonner, A., \& Francis, K. (2007). Grounded theory: A methodological spiral from positivism to postmodernism. Journal of Advanced Nursing, 58(1), 72-79.

Morrison, K. A., Robbins, H. H., \& Rose, D. G. (2008). Operationalizing culturally relevant pedagogy: A synthesis of classroom-based research. Equity \& Excellence in Education, 41(4), 433-452.

Mulryan-Kyne, C. (2010). Teaching large classes at college and university levels: challenges and opportunities. Teaching in Higher Education, 15(2), 175-185.

Orelus, P. (2011). When theory walks with praxis: Critical pedagogy and the light of transnational and postcolonial subjects of color. In S. Malott \& B. Porfilio (Eds.), Critical pedagogy in the 21st-century: A new generation of scholars (pp. 3-21). Charlotte, NC: Information Age.

Portelli, J. P., Vibert, A., \& Shields, C. (2007). Toward an equitable education: Poverty, diversity, and students at risk: The national report. Toronto, ON: Ontario Institute for Studies in Education.

Shor, I. (1993). Paulo Freire’s critical pedagogy. New York, NY: Routledge.

Shor, I., \& Pari, C. (1999). Critical literacy in action: Writing words, changing worlds. Portsmouth, NH: Boynton/Cook.

Solomon, R. P., Portelli, J., Daniel, B., \& Campbell, A. (2005). The discourse of denial: How white teacher candidates construct race, racism and "white privilege." Race, Ethnicity and Education, 8(2), 147-169.

Solomon, R. P., Singer, J., Campbell, A., \& Allen, A. (2011). Brave new teachers: Doing social justice work in neo-liberal times. Toronto, ON: Canadian Scholars' Press

Strauss, A., \& Corbin, J. M. (1998). Basics of qualitative research: Techniques and procedures for developing grounded theory. Thousand Oaks, CA: Sage. 


\section{BIOGRAPHICAL NOTE:}

Barbara Anne Pollard conducts research in the areas of critical literacy and critical pedagogy, and explores neoliberal implications on Canadian educational systems. Pollard utilizes critical, feminist, and intersectional theoretical frameworks to emphasize and create strategies to address the inequitable social and educational outcomes experienced by marginalized students. Pollard has had the privilege and pleasure of teaching a wide range of courses at the Faculty of Education (University of Windsor) at the preservice and graduate level. Most recently, Pollard has been awarded a Social Science and Humanities Research Partnership Grant to enhance and scale up a local sport equity program focused on facilitating leadership skills and developing the confidence levels of underserviced elementary girls. 


\section{APPENDIX A}

\section{Script for Initial Interviews with Faculty Participants Purpose of the Study}

Previously, you were informed that the purpose of the study was to explore how critical pedagogy influences the student's ability to think critically about issues of inequity. The purpose of this interview is to document your critical teaching and learning philosophy. I will be asking you a few questions about the foundational theories that guide your teaching and the teaching practices that support these theories.

Confidentiality: You may decide that you want to withdraw from the study or do not want your data used in this research. If this is the case, please contact the researcher with this request either in person XXX, email XXX or alternatively, through phone correspondence at XXX.

\section{Guiding Interview Questions for Faculty:}

1) Do you identify as a "critical pedagogue" and what does that mean to you?

2) How do you define the term "critical pedagogy"?

3) Which theories and theorists do you refer to for guidance?

4) What are the key learning outcomes of your teaching practice?

5) What specific teaching practices or strategies do you implement to reach the intended learning outcomes?

6) Can you describe your thought process when designing or redesigning your course syllabus?

7) What kinds of challenges are associated with your teaching approach or instructional practices?

8) Is there anything else you would like to add that you think is a key factor in this study or interview process?

9) Do you have any questions at this point?

Useful Contact Information: If you have any questions or concerns regarding this study, its purpose or procedures, or if you have a research-related problem, please feel free to contact the researcher.

\section{Thank you for participating in this study.}

Your time and insight is much appreciated. 


\section{APPENDIX B}

\section{Guiding Interview Questions: \\ Reflecting On and Documenting Key Critical Learning Experiences while Being Taught by a Critical Educator}

\section{Phase One Data Collection Interview Questions:}

1) Within the world of teaching, what does the phrase, diverse students, mean to you? Please explain.

2) Do you ever think about how your teaching practice will impact the minority students in your classroom? If so, please explain how.

3) Do you have any interest in teaching for social justice? If so, please explain why and how you may do this?

4) How do you feel about the following statement: Generally speaking, women, poor children, and certain racialized groups and ethnicities have fewer chances to get a good education and get ahead in life? Please explain and justify your feelings and thoughts on this statement. (The components of this question are modifications from the work of Diemer, Luke, Rapa \& Catalina, 2014)

5) Do you ever critically reflect on how your identity (e.g. race, gender, social class among other factors) will impact your relationship with future students? If so, how? Please explain. 


\section{APPENDIX C}

\section{Guiding Interview Questions:}

Reflecting On and Documenting Key Critical Learning Experiences while Being Taught by a Critical Educator

\section{Phase Two Data Collection Interview Questions:}

1. What are your core values, what beliefs drive you? Name three core values that define who you are.

2. As you think back to your learning experiences within the context of your critical pedagogy class with [instructor's name], what resonates most with you?

3. Describe how your knowledge/beliefs about diverse students has changed as a result of being in [instructor name's] critical pedagogy class?

4. Describe how your knowledge/beliefs about the role of teachers has changed as a result of being in [instructor name's] critical pedagogy class?

5. Describe some specific examples of your socially just teaching practice?

6. What specific readings, discussions, field experiences had the greatest impact on your social justice teaching practices?

7. What experiences BEFORE the program had the greatest impact on your knowledge, attitudes and skills related to teaching for social justice?

8. What experiences DURING the program had the greatest impact on your knowledge, attitudes and skills related to teaching for social justice?

9. What suggestions do you have for making the class stronger in its efforts to develop socially just teachers? 